\title{
Occurrence of exo- and endopeptidases in dissolved and particulate fractions of coastal seawater
}

\author{
Yumiko Obayashi ${ }^{1,2, *}$, Satoru Suzuki ${ }^{1}$ \\ ${ }^{1}$ Center for Marine Environmental Studies, Ehime University, Matsuyama, Ehime 790-8577, Japan \\ ${ }^{2}$ Division of Natural Sciences, International Christian University, Mitaka, Tokyo 181-8585, Japan
}

\begin{abstract}
We analyzed potential activities of different proteolytic enzymes in size-fractionated seawater, and estimated the contribution of each size fraction $(<0.2,0.2-0.8,0.8-5$, and $>5 \mu \mathrm{m})$ to the bulk hydrolytic activity of each enzyme in the seawater. The activity of leucine-aminopeptidase was highly attributed to cell-associated size fractions, while the contribution of the dissolved fraction $(<0.2 \mu \mathrm{m})$ to the bulk activity was only 10 to $30 \%$. In contrast, the contribution of the dissolved fraction to the activities of the trypsin- and chymotrypsin-type endopeptidases was as high as 40 to $80 \%$ of their bulk activities measured in unfiltered seawater. These results indicated the potential importance of free proteolytic enzymes in seawater, especially for endopeptidases. Significant enzymatic activity in the dissolved fraction was also detected from experiments with isolated bacteria, suggesting that direct secretion of proteases from marine bacteria into surrounding water could be at least one of the sources of the dissolved proteolytic enzymes in seawater. Generally, the natural bacterial community of seawater was able to hydrolyze all of the 16 tested substrates, but at different rates. Selected members of the community (3 bacterial isolates and Synechococcus) hydrolyzed only one or a few of the applied substrates, and the substrate preference varied among the strains. These results suggest that natural bacterial communities are composed of a great variety of bacterial species with different (specific) enzymatic properties, including dissolved endopeptidases and cell-associated aminopeptidase. The combined activities of these enzymes are responsible for an effective degradation and re-use of high molecular weight organic matter at the community level.
\end{abstract}

KEY WORDS: Extracellular enzyme - Endopeptidase - Aminopeptidase - Dissolved fraction · Cell-associated fraction $\cdot$ Microbial loop $\cdot$ Organic matter degradation

Resale or republication not permitted without written consent of the publisher

\section{INTRODUCTION}

Microbial utilization of dissolved and particulate organic matter (DOM and POM) is the nutritional basis of the microbial food web (Azam 1998). Prior to the bacterial utilization of high-molecular weight DOM, enzymatic hydrolysis outside the cells is needed, since only relatively small molecules (less than around $600 \mathrm{Da}$ ) can be readily transported across the bacterial membrane. For bacteria attached to the particles, hydrolytic enzymes outside the cells are also necessary to solubilize POM before its uptake (Smith et al. 1992). Thus, the enzymatic activities outside the cells consti- tute the initial step of organic matter conversion and define the type and quantity of substrates available to the microbial food web in aquatic ecosystems. The activities of various hydrolytic enzymes in aquatic ecosystems have been investigated to describe the microbial activity and dynamics of organic matter conversion (reviewed by Hoppe et al. 2002).

For the effective hydrolysis of high molecular weight DOM and POM, the importance of endohydrolases (that can cleave a bond in the inner region of a polymer) in aquatic ecosystems has been pointed out (Carlson 2002, Hoppe et al. 2002). However, the information on endohydrolases in the sea is very limited compared 
with that on exohydrolases, which act on the terminal ends of the polymer and release a monomeric substance. Currently, the proteolytic activity in seawater has been investigated mainly by using a model substrate for leucine-aminopeptidase, a kind of exopeptidase (Hoppe 1983, Somville \& Billen 1983), and only a few investigations about endopeptidase have been reported (Hollibaugh \& Azam 1983, Pantoja et al. 1997, Obayashi \& Suzuki 2005). Obayashi \& Suzuki (2005) investigated the activities of proteolytic enzymes in bulk seawater and revealed significant activities of both endopeptidases and exopeptidases. For leucineaminopeptidase activity in the sea, some studies examined size-fractionated samples and reported that it was mostly attributed to the cell-surface associated enzyme (Vives Rego et al. 1985, Rosso \& Azam 1987). Karner \& Rassoulzadegan (1995) considered the importance of free (dissolved) enzyme, which was estimated to be 30 to $40 \%$ of total aminopeptidase activity in a coastal ecosystem. However, the state of the existence of endopeptidases in the marine environment has not yet been investigated in detail. In the present study, we measured the potential activities of proteolytic enzymes, including endopeptidases and aminopeptidases, in size-fractionated seawater to investigate the predominant state of existence of each type of enzyme. Additionally, we also tested some bacterial isolates derived from natural seawater to confirm the microbial origin of proteolytic activity in seawater.

\section{MATERIALS AND METHODS}

Seawater samples. Surface seawater samples were collected with a plastic bucket from a coastal site of Matsuyama in Ehime Prefecture, Japan, between August 2003 and April 2004. There was no river inflow near the sampling site. All sampling was conducted at around $1 \mathrm{~h}$ before high tide during the daytime. Surface seawater temperature at the sampling site was the highest $\left(23^{\circ} \mathrm{C}\right)$ in September and the lowest $\left(12^{\circ} \mathrm{C}\right)$ from January to March. Seawater samples were immediately poured into $1 \mathrm{l}$ bottles through a $150 \mu \mathrm{m}$ nylon mesh to remove large organisms and particles. Each of 3 aliquots of seawater samples was gently $(0.005 \mathrm{MPa})$ filtered through a $0.2,0.8$ or $5 \mu \mathrm{m}$ poresize polycarbonate Nuclepore filter (Whatman), respectively. Each of the filtrates and the unfiltered seawater were kept cool and used for protease assay within $12 \mathrm{~h}$.

Activity of proteolytic enzymes. Enzymatic activity was assayed using peptide analog 4-methyl-coumaryl7-amide (MCA) substrates (Peptide Institute). Sixteen MCA substrates, including substrates for aminopeptidase, trypsin and chymotrypsin (Table 1), were used to examine substrate preference for enzymes in the seawater and bacterial suspensions. For the seawater samples taken on 25 March and 25 April 2004, 3 additional substrates for aminopeptidase were also tested.

Table 1. Substrates used in the present study. MCA = 4-methyl-coumaryl-7-amide

\begin{tabular}{|lccl|}
\hline Name & $\begin{array}{c}\text { Substrate } \\
\text { for }\end{array}$ & $\begin{array}{c}\text { Molecular } \\
\text { weight }\end{array}$ & \multicolumn{1}{c|}{ Compound } \\
\hline Arg-MCA & Aminopeptidase & 331.37 & L-arginine MCA \\
Leu-MCA & Aminopeptidase & 288.35 & L-leucine MCA \\
Ala-MCA & Aminopeptidase & 246.27 & L-alanine MCA \\
Lys-MCA $^{\text {a }}$ & Aminopeptidase & 303.36 & L-lysine MCA \\
Phe-MCA & Aminopeptidase & 322.36 & L-phenylalanine MCA \\
Bz-Arg-MCA & Trypsin & 435.48 & Benzoyl-L-arginine MCA \\
Z-Phe-Arg-MCA & Trypsin & 612.69 & Carbobenzoxy-L-phenylalanyl-L-arginine MCA \\
Glt-Gly-Arg-MCA & Trypsin & 502.53 & Glutaryl-glycyl-L-arginine MCA \\
Boc-Leu-Gly-Arg-MCA & Trypsin & 601.70 & t-butyloxycarbonyl-L-leucyl-glycyl-L-arginine MCA \\
Boc-Leu-Thr-Arg-MCA & Trypsin & 645.76 & t-butyloxycarbonyl-L-leucyl-L-threonyl-L-arginine MCA \\
Boc-Phe-Ser-Arg-MCA & Trypsin & 665.75 & t-butyloxycarbonyl-L-phenylalanyl-L-seryl-L-arginine MCA \\
Boc-Val-Pro-Arg-MCA & Trypsin & 627.74 & t-butyloxycarbonyl-L-valyl-L-prolyl-L-arginine MCA \\
Boc-Leu-Ser-Thr-Arg-MCA & Trypsin & 732.83 & t-butyloxycarbonyl-L-leucyl-L-seryl-L-threonyl-L-arginine MCA \\
Boc-Val-Leu-Lys-MCA & Trypsin & 615.77 & t-butyloxycarbonyl-L-valyl-L-leucyl-L-lysine MCA \\
Boc-Glu-Lys-Lys-MCA & Trypsin & 660.77 & t-butyloxycarbonyl-L-glutamyl-L-lysyl-L-lysine MCA \\
Suc-Ala-Ala-Pro-Phe-MCA & Chymotrypsin & 661.71 & Succinyl-L-alanyl-L-alanyl-L-prolyl-L-phenylalanine MCA \\
Suc-Leu-Leu-Val-Tyr-MCA & Chymotrypsin & 763.89 & Succinyl-L-leucyl-L-leucyl-L-valyl-L-tyrosine MCA \\
Suc-Ala-Ala-Ala-MCA & Elastase & 488.50 & Succinyl-L-alanyl-L-alanyl-L-alanine MCA \\
Suc-Ala-Pro-Ala-MCA & Elastase & 514.54 & Succinyl-L-alanyl-L-prolyl-L-alanine MCA \\
& & & \\
aAla-MCA, Lys-MCA and Phe-MCA were used only for & the seawater samples taken on 25 March and 25 April 2004. Other \\
samples of seawater and bacterial culture were tested & by 16 substrates \\
& & & \\
\hline & & & \\
\hline & &
\end{tabular}


All substrates were prepared as a $1 \mathrm{mM}$ stock in dimethyl sulfoxide (superior grade; Wako Chemical). Incubation tubes were filled with $100 \mu \mathrm{l}$ aliquots of the stock solution and stored frozen until use. For assays, a $900 \mu \mathrm{l}$ sample was added to each tube to yield a final substrate concentration of $100 \mu \mathrm{M}$; this concentration was previously confirmed as the saturation level for at least Leu-MCA and Boc-Phe-Ser-Arg-MCA (see Table 1) (Obayashi \& Suzuki 2005). One exception was the 30 September 2003 experiment in which we used a final substrate concentration of $150 \mu \mathrm{M}$ using $15 \mu \mathrm{l}$ of $10 \mathrm{mM}$ stock solution.

Mixtures of sample and substrate were incubated at $25^{\circ} \mathrm{C}$ for $1 \mathrm{~h}$, before and after which the fluorescence of the hydrolytic product, 7-amino-4-methylcoumarin (AMC), was measured with a spectrofluorometer (Hitachi F-2500) at an excitation/emission wavelength of $380 / 460 \mathrm{~nm}$. After subtracting the blank fluorescence intensity of each water sample (measured without an added substrate), the concentration of AMC in the incubation tube was calculated using a calibration curve obtained from several concentrations of standard AMC. For the control, autoclaved filtered seawater was assayed using the same method as that described for the samples and was used to determine the non-enzymaticproduced AMC. The hydrolysis rates of substrate were estimated from the change in the concentration of AMC in the incubation tube after the concentration of nonenzymatic-produced AMC was subtracted.

The enzymatic activities derived from each size fraction were calculated by the difference between 2 sizefractionated filtrates, e.g. the activity in the 0.2 to $0.8 \mu \mathrm{m}$ fraction was calculated from the difference between the measured activity in the $<0.8 \mu \mathrm{m}$ filtrate (filtrate that passed through a $0.8 \mu \mathrm{m}$ pore-size filter) and that in the $<0.2 \mu \mathrm{m}$ filtrate.
Bacterial suspension. Three bacterial strains were isolated from the agar plates of the January 2004 investigation. Seawater was spread on Marine Broth 2216 (Difco) plus 1.5\% agar plates. Typical colonies were isolated and the strains $\mathrm{W}, \mathrm{Y}$ and $\mathrm{O}$ were employed for this study. Colonies of the strains W, Y and $\mathrm{O}$ showed white, yellow and orange color, respectively. The classification status of these strains was not examined. The colony picked from the plate was suspended into autoclaved filtered seawater and incubated at $25^{\circ} \mathrm{C}$ for $40 \mathrm{~h}$ with mild shaking. After incubation, proteolytic activity in the bacterial suspension was analyzed using the same method described for the natural seawater samples. Synechococcus sp. strain (from Dr. Koji Suzuki, Hokkaido University, Japan) was tested in addition to the 3 heterotrophic bacterial isolates because Martinez \& Azam (1993) reported that marine cyanobacteria had aminopeptidase activity. After incubation, 2 aliquots of bacterial suspension of strain $\mathrm{W}$ were gently filtered through 0.2 and $0.8 \mu \mathrm{m}$ Nuclepore filters, respectively. Each of the filtrates was also used for protease assay.

\section{RESULTS}

\section{Enzymatic activity and size distribution in natural seawater}

A typical pattern of hydrolysis rates (30 December) of 16 substrates in natural seawater and the contribution of each size fraction to those rates are shown in Fig. 1. The substrates for aminopeptidase, trypsin and chymotrypsin were hydrolyzed, but those for elastase were barely hydrolyzed in the unfiltered seawater (Fig. 1a), as described in Obayashi \& Suzuki (2005).
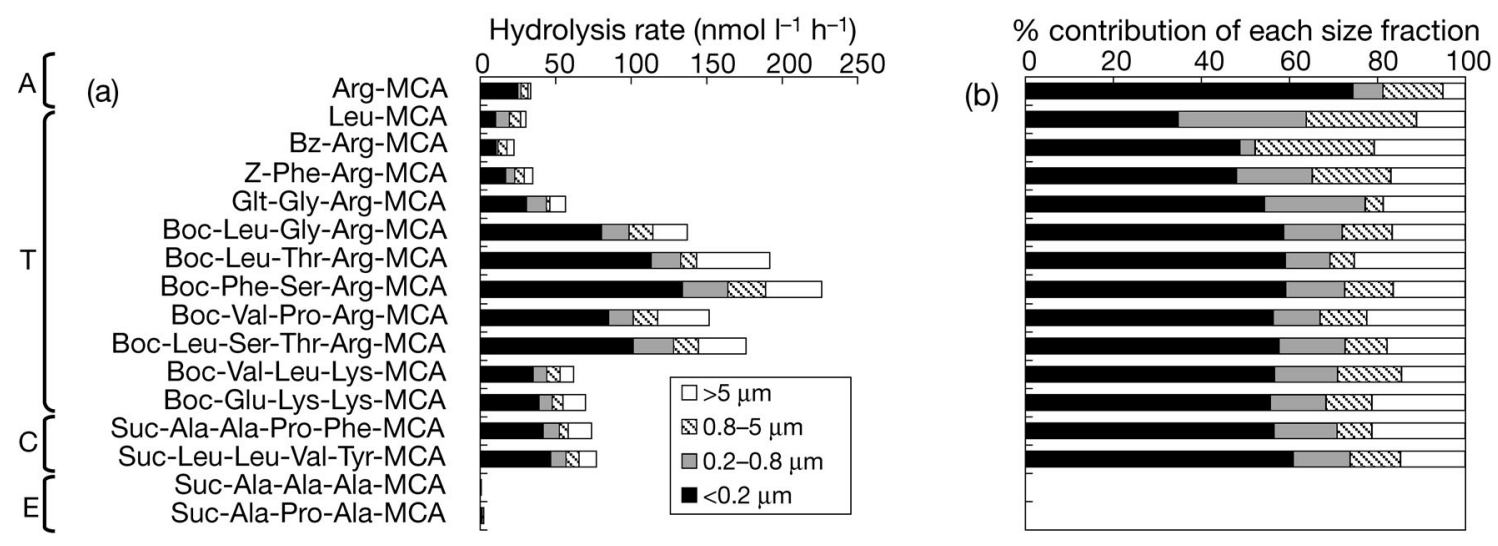

Fig. 1. (a) Typical pattern of hydrolysis rates of 16 substrates with size-fractionation and (b) percent contribution of each size fraction described in (a) to the bulk hydrolysis activity estimated in the unfiltered seawater. This sample was taken on 30 December 2003. The names of substrates are shown in Table $1 . \mathrm{A}=$ substrates for aminopeptidase, $\mathrm{T}=$ substrates for trypsin, $\mathrm{C}=$ substrates for chymotrypsin, E = substrates for elastase 


\begin{tabular}{|ll|}
$\square>5 \mu \mathrm{m}$ & $\square 0.2-0.8 \mu \mathrm{m}$ \\
$\square 0.8-5 \mu \mathrm{m}$ & $\square<0.2 \mu \mathrm{m}$ \\
\hline
\end{tabular}

(a) Leu-MCA

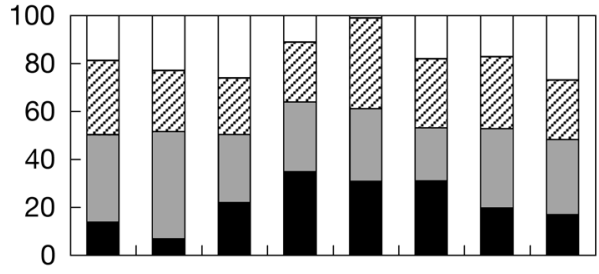

(b) Boc-Phe-Ser-Arg-MCA

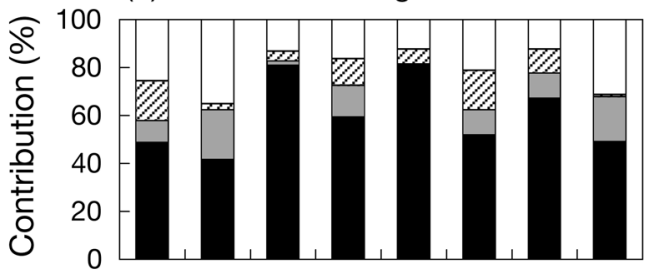

(c) Suc-Ala-Ala-Pro-Phe-MCA

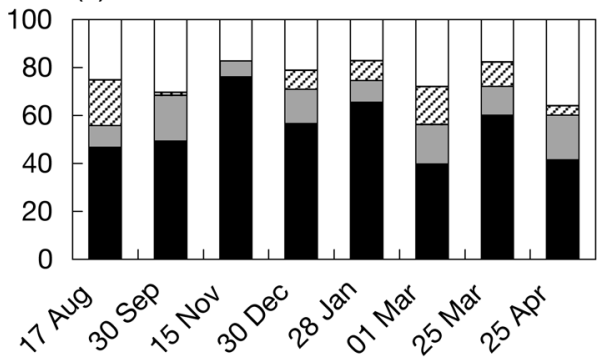

Fig. 2. Percent contribution of each size fraction to enzymatic hydrolysis of (a) Leu-MCA (substrate for leucine-aminopeptidase), (b) Boc-Phe-Ser-Arg-MCA (substrate for trypsin) and (c) Suc-Ala-Ala-Pro-Phe-MCA (substrate for chymotrypsin) during 8 observations

In general, the $<0.2 \mu \mathrm{m}$ size fraction is considered to be the 'dissolved fraction', and the 0.2 to $0.8 \mu \mathrm{m}$ fraction is considered to contain small free-living bacterial cells. Larger size fractions ( 0.8 to $5 \mu \mathrm{m}$ and $>5 \mu \mathrm{m})$ contain both larger organisms, such as flagellates and ciliates, and aggregates or particle-attached bacteria. More than half (50 to $60 \%$ ) of the hydrolysis of all 10 substrates for trypsin and 2 for chymotrypsin was attributed to the dissolved fraction $(<0.2 \mu \mathrm{m})$ (Fig. 1b). The contribution of the dissolved fraction to hydrolysis of Leu-MCA (substrate for leucine-aminopeptidase), however, was less than that of the substrates for trypsin and chymotrypsin.

The variation of the contribution of each size fraction to the enzymatic activities that hydrolyzed Leu-MCA (substrate for leucine-aminopeptidase), Boc-Phe-SerArg-MCA (substrate for trypsin), and Suc-Ala-AlaPro-Phe-MCA (substrate for chymotrypsin) during 8 observations conducted between August 2003 and
April 2004 is shown in Fig. 2. The contributions of the dissolved fraction $(<0.2 \mu \mathrm{m})$ to hydrolysis of the LeuMCA in bulk seawater were about 10 to $30 \%$ throughout the period, and the activity was attributed mainly to cell-associated size fractions (Fig. 2a). In contrast, 40 to $80 \%$ of hydrolysis of Boc-Phe-Ser-Arg-MCA and Suc-Ala-Ala-Pro-Phe-MCA were attributed to the dissolved fraction, with the importance of the cell-associated size fraction being less significant compared with that of Leu-MCA (Fig. 2b,c).

No significant relationship was found between the hydrolytic activity in bulk seawater and the percentage contribution of the dissolved fraction to that activity (Fig. 3a). For trypsin-type enzymes, even if the activity reached a very high value, around $50 \%$ was attributed to the dissolved fraction. Although the values varied among 8 observations, on average, around

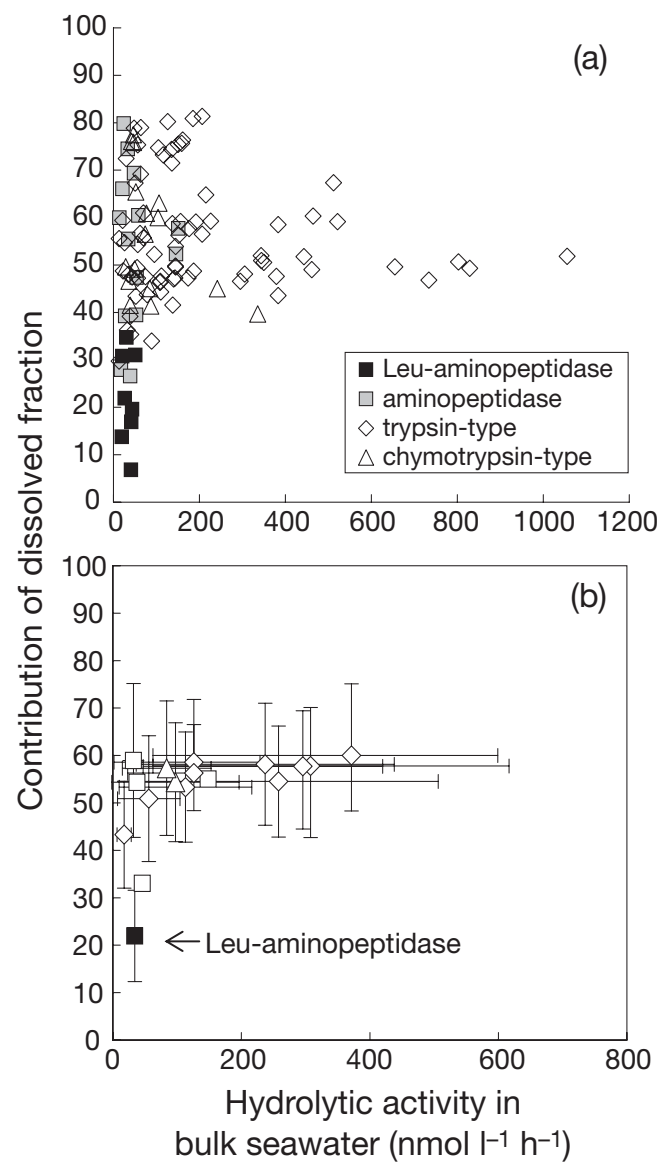

Fig. 3. (a) Hydrolytic activity estimated using each substrate in the bulk seawater and the percent contribution of the dissolved fraction $(<0.2 \mu \mathrm{m})$ to the hydrolysis. Symbols are distinguished by the type of the substrate shown in Table 1. Data obtained from the hydrolysis of Leu-MCA were shown separately from those of the other substrates for aminopeptidase. (b) The same plot as (a) using averaged hydrolytic activity and averaged contribution of the 8 observations for each substrate. Bars are SD values obtained from the 8 observations 


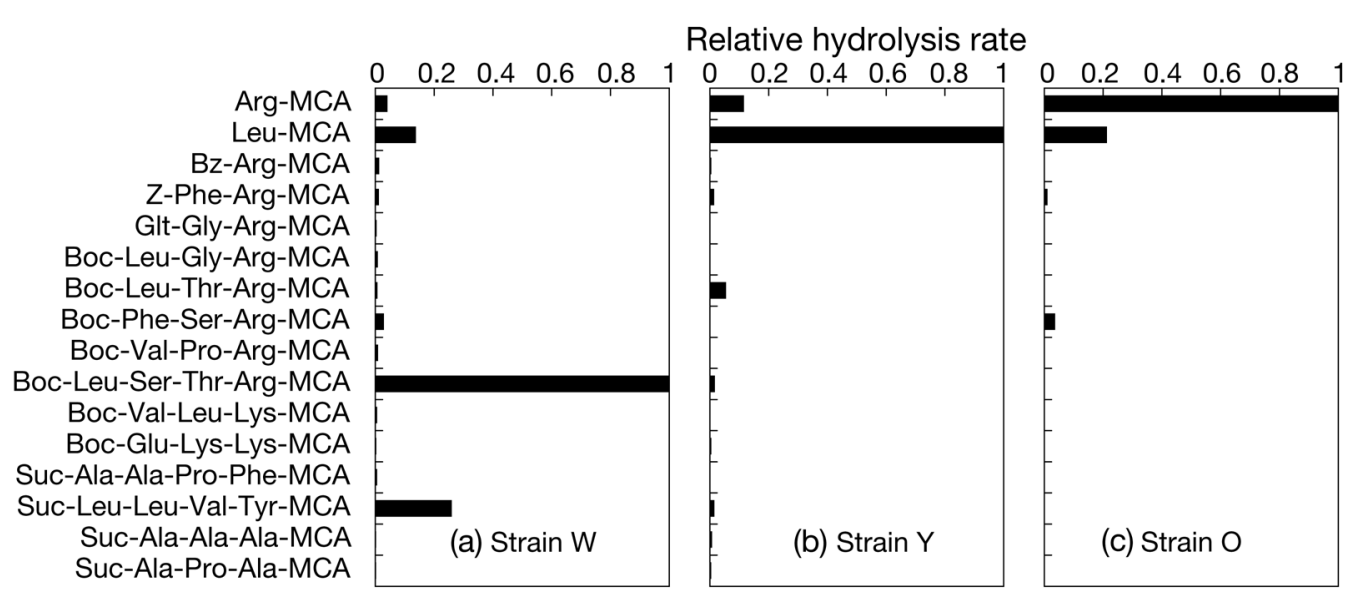

Fig. 4. Hydrolysis patterns of 16 substrates in the culture fluid of (a) strain W, (b) strain Y, (c) strain O. Relative hydrolysis rate of each substrate is expressed as the ratio of the substrate with maximum hydrolysis rate

50 to $60 \%$ of hydrolysis of most substrates for trypsin and chymotrypsin were attributed to the dissolved fraction, while only $22 \%$ of the bulk leucine-aminopeptidase activity was attributed to the dissolved fraction (Fig. 3b). According to a $t$-test using the average of 8 observations for each substrate, these percent values (percent contributions of dissolved fraction to the bulk hydrolytic activity) for all tested substrates were significantly higher $(\mathrm{p}<0.001$, except for BzArg-MCA, where $\mathrm{p}<0.01$ ) than that observed for Leu-MCA.

\section{Enzymatic activity in the bacterial suspension}

Substrate specificity of the 3 bacterial isolates was different (Fig. 4). Strain W hydrolyzed Boc-Leu-SerThr-Arg-MCA (substrate for trypsin) and Suc-LeuLeu-Val-Tyr-MCA (substrate for chymotrypsin) at a noticeably higher rate than Leu-MCA, whereas LeuMCA was the most hydrolyzed substrate in the suspension of strain Y. Strain O hydrolyzed mainly Arg-MCA and Leu-MCA with a little hydrolysis of Boc-Phe-SerArg-MCA (substrate for trypsin). Synechococcus hydrolyzed only Leu-MCA among the 16 substrates tested (data not shown).

The contribution of each size fraction to hydrolysis was estimated for strain W (Fig. 5). The aminopeptidase activities (hydrolysis of Leu-MCA and Arg-MCA) were high in the bacterial size fraction $(0.2$ to $0.8 \mu \mathrm{m})$. The percent contribution of the dissolved fraction to hydrolysis of Boc-Leu-Ser-Thr-Arg-MCA (substrate for trypsin) and Suc-Leu-Leu-Val-Tyr-MCA (substrate for chymotrypsin) were to a great extent higher than those of Leu-MCA and Arg-MCA (substrates for aminopeptidase) (Fig. 5).

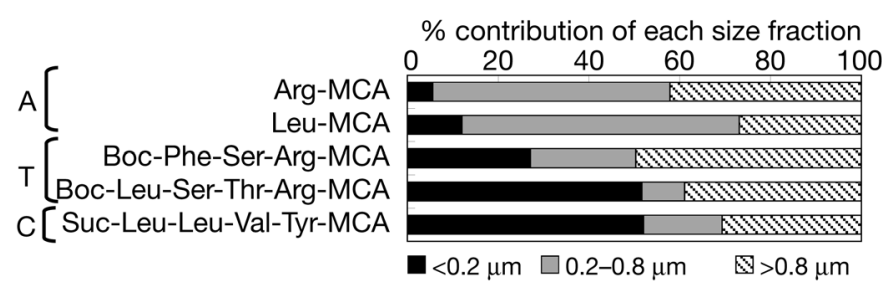

Fig. 5. Percent contribution of each size fraction to enzymatic hydrolysis in the culture of strain $\mathrm{W}$. The assay was performed for Arg-MCA, Leu-MCA, Boc-Phe-Ser-Arg-MCA, Boc-LeuSer-Thr-Arg-MCA and Suc-Leu-Leu-Val-Tyr-MCA, which were significantly hydrolyzed as shown in Fig. 4a

\section{DISCUSSION}

Previous studies of bacterial hydrolases in aquatic environments have reported that hydrolytic activities are largely associated with cell surface rather than dissolved fractions in seawater, although some studies pointed out the importance of cell-free enzymes (Hoppe et al. 2002). As for proteolytic enzymes, these reports were derived from the results of investigations on leucine-aminopeptidase (Vives Rego et al. 1985, Rosso \& Azam 1987, Karner \& Rassoulzadegan 1995). In our study, although 10 to $30 \%$ of the leucineaminopeptidase activity was attributed to the dissolved fraction, bulk leucine-aminopeptidase activity was dominated by the cell- and particle-related fractions (Figs. 1 \& 2a), which is in agreement with the previously mentioned studies. In contrast, the dissolved fraction dominated hydrolysis of the other substrates. All of the substrates for trypsin and chymotrypsin were strongly hydrolyzed in the dissolved fraction, even when the bulk activity was very high (Fig. 3), which in the 8 observations averaged 50 to $60 \%$. These results 
indicate the potential importance of free dissolved enzymes in seawater, especially for endopeptidases.

The contributions of the dissolved fraction to hydrolysis of the other substrates for aminopeptidase (Arg-MCA, Ala-MCA, Lys-MCA and Phe-MCA) also tended to be higher than that for Leu-MCA (Fig. 3). Because the contribution of dissolved fraction for ArgMCA varied among the 8 observations and the data for Ala-MCA, Lys-MCA and Phe-MCA were limited in this study, it is not clear whether the distribution of high activity on the cell surface rather than in the dissolved fraction is a specific characteristic of leucineaminopeptidase or a more general feature of aminopeptidases or exopeptidases. However, the results of this study showed that the dissolved fractions of trypsin-type and chymotrypsin-type endopepeptidases contributed much more to the total activity of these enzymes in unfiltered seawater than the dissolved fraction did for leucine-aminopeptidase. This suggests that there are differences between exopeptidases and endopeptidases not only with respect to their cleavage site, but also to their preferred state in the marine environment. Debroas (1998) measured activities of aminopeptidase and endopeptidase in size-fractionated lake water using Leu-MCA and fluorescein isothiocyanate casein (FTC-casein). They reported that the proportion of the endopeptidase activity in the $<1.2 \mu \mathrm{m}$ fraction was higher than that of the aminopeptidase activity. Our results in seawater are supported by the observations of Debroas (1998), although he did not separate the $<0.2 \mu \mathrm{m}$ (dissolved) fraction from the $<1.2 \mu \mathrm{m}$ (dissolved + small cells) fraction for measuring the endopeptidase. Our study suggests that marine bacteria might be using 'dissolved' endopeptidases, which cleave peptide bonds in the inner region of the polypeptide molecule and produce shorter peptides, prior to hydrolysis releasing monomer from the terminus of oligopeptides by cell-surface exopeptidases such as leucine-aminopeptidase.

Several organisms and processes may be considered as potential sources for the release of hydrolytic enzymes dissolved in seawater. For example, cell lysis accompanied by grazing and virus infection on bacteria and plankton may release free enzymes into seawater (Karner et al. 1994, Mohapatra \& Fukami 2004). Stoecker \& Gustafson (2003) reported cell surface proteolytic activity of dinoflagellates. Flagellates may contribute also to free enzymes by excretion. Trypsin and chymotrypsin occur in the digestive tract and feces of fishes and zooplankton (Córdova-Murueta et al. 2003). Although the contribution of the digestive enzymes diffusing from the feces or being excreted by these organisms has not yet been revealed, these processes may also be one of the potential sources of dissolved trypsin- and chymotrypsin-type enzymes in seawater.
In our results using bacterial strain $\mathrm{W}$ suspended in autoclaved filtered seawater, we detected significant enzymatic activity in the dissolved fraction (Fig. 5), which indicates that some enzymes were released from bacterial cells into the surrounding water. Moreover, the results of strain $\mathrm{W}$ after size fractionation (Fig. 5) seem to have similar features to those obtained from the size fractionated natural seawater (Figs. 1 \& 2 ), namely, the high contribution of the cell size fraction to aminopeptidase activity and the high contribution of the dissolved fraction to the trypsin- and chymotrypsin-type activities. We cannot conclude what is the 'major' source of dissolved enzymes in natural seawater; however, these results suggest that direct secretion of 'free' enzyme from marine bacteria should be at least one of the sources of dissolved proteolytic enzymes in seawater.

In aquatic environments, the release of 'free' extracellular enzymes might appear to be ineffective given that released enzymes and hydrolysis products can be lost by diffusion. However, Wetzel (1991) estimated that, although products would diffuse away from the cell, these losses may be compensated for by the better availability of substrates if the hydrolyzed molecules are within a distance of about $500 \mu \mathrm{m}$ from the cell surface. Vetter et al. (1998) also pointed out the importance of 'cell-free' enzymes to bacterial foraging in the environment on the basis of their predictive model. In addition, Hoffman \& Decho (2000) reported on secreted enzymes from a cultured marine bacterium and the flexibility of these enzymes towards changing microenvironments.

In particulate fractions $(0.2$ to $0.8,0.8$ to 5 , and $>5 \mu \mathrm{m})$, possible sources of cell- or particle-associated enzymes might be free-living bacteria ( 0.2 to $0.8 \mu \mathrm{m}$ size fraction), aggregates (Müller-Niklas et al. 1994) or particle-attached bacteria (Karner \& Herndl 1992, Martinez et al. 1996), prokaryotic phytoplankton (Martinez \& Azam 1993) and eukaryotic phytoplankton (Stoecker \& Gustafson 2003). In the estimated activities of the $>5 \mu \mathrm{m}$ size fraction, methodological effects associated with the filtration process may be easily included compared with other fractions, since the value was calculated by the difference between the activities measured in unfiltered seawater and filtrates passed through a $5 \mu \mathrm{m}$ pore-size filter. The estimated contribution of the $>5 \mu \mathrm{m}$ size fraction might be overestimated, considering adsorption of enzymes onto a filter during the filtration (Obayashi \& Suzuki in press).

The 3 bacterial isolates and Synechococcus showed different hydrolysis patterns (Fig. 4). Each strain specifically hydrolyzed one or several substrates. However, all of the tested substrates for aminopeptidase, trypsin and chymotrypsin were hydrolyzed in the seawater, although the rates varied among the substrates 
(Fig. 1). These results suggested that, even though each microorganism can degrade a rather limited range of substrates, a much greater variety of substrates could be used by the microbial community in the seawater. Arrieta \& Herndl (2002) reported the diversity of bacterial $\beta$-glucosidase and the possibility of its regulation by shifts in the bacterial community structure. Arnosti et al. (2005) also showed that the diversity of enzymes that degrade polysaccharides in the ocean was consistent with the diversity of microbial communities. Although the results of this study were derived from only 1 coastal site and the microbial diversity was not tested, they also seem to imply that the diverse microorganisms in the seawater provided diverse proteases including 'dissolved endopeptidases' and 'cell-associated aminopeptidase' to degrade and utilize high molecular weight dissolved organic molecules efficiently at the community level.

Acknowledgements. We thank S.-I. Kitamura and A. Igarashi for their kind cooperation in the sample collection. We also thank K. Suzuki for providing the Synechococcus sp. strain and T. Miller for his kind editorial suggestions. The manuscript has much benefited from the comments and suggestions from the 2 anonymous reviewers. This work was partly supported by the 21st Century COE Program and the GlobalCOE Program at Ehime University, Academic Frontier Project at International Christian University, Grant-in-aid for Scientific Research (No. 17710015) from the Ministry of Education, Culture, Sports, Science and Technology of Japan, and Kurita Water and Environmental Foundation Research Grant to Y.O.

\section{LITERATURE CITED}

Arnosti C, Durkin S, Jeffrey WH (2005) Patterns of extracellular enzyme activities among pelagic marine microbial communities: implications for cycling of dissolved organic carbon. Aquat Microb Ecol 38:135-145

Arrieta JM, Herndl GJ (2002) Changes in bacterial $\beta$-glucosidase diversity during a coastal phytoplankton bloom. Limnol Oceanogr 47:594-599

Azam F (1998) Microbial control of oceanic carbon flux: the plot thickens. Science 280:694-696

Carlson CA (2002) Production and removal processes. In: Hansell DA, Carlson CA (eds) Biogeochemistry of marine dissolved organic matter. Academic Press, San Diego, CA, p 91-151

Córdova-Murueta JH, García-Carreño FL, Navarrette-delToro MA (2003) Digestive enzymes present in crustacean feces as a tool for biochemical, physiological, and ecological studies. J Exp Mar Biol Ecol 297:43-56

Debroas D (1998) Decomposition of protein compounds in an eutrophic lake: spatial and temporal distribution of exopeptidase and endopeptidase activities in various size fractions. Hydrobiologia 382:161-173

Hoffman M, Decho AW (2000) Proteolytic enzymes in the marine bacterium Pseudoalteromonas atlantica: postsecretional activation and effects of environmental conditions. Aquat Microb Ecol 23:29-39

Hollibaugh JT, Azam F (1983) Microbial degradation of dis- solved proteins in seawater. Limnol Oceanogr 28: 1104-1116

Hoppe HG (1983) Significance of exoenzymatic activities in the ecology of methylumbelliferyl-substrates. Mar Ecol Prog Ser 11:299-308

Hoppe HG, Arnosti C, Herndl GJ (2002) Ecological significance of bacterial enzymes in the marine environment. In: Burns RG, Dick RP (eds) Enzymes in the environment. Activity, ecology, and applications. Marcel Dekker, New York, p 73-107

Karner M, Herndl GJ (1992) Extracellular enzymatic activity and secondary production in free-living and marinesnow-associated bacteria. Mar Biol 113:341-347

Karner M, Rassoulzadegan F (1995) Extracellular enzyme activity: indications for high short-term variability in a coastal marine ecosystem. Microb Ecol 30:143-156

Karner M, Ferrier-Pagès C, Rassoulzadegan F (1994) Phagotrophic nanoflagellates contribute to occurrence of $\alpha$-glucosidase and aminopeptidase in marine environments. Mar Ecol Prog Ser 114:237-244

Martinez J, Azam F (1993) Aminopeptidase activity in marine chroococcoid cyanobacteria. Appl Environ Microbiol 59: 3701-3707

Martinez J, Smith DC, Steward GF, Azam F (1996) Variability in ectohydrolytic enzyme activities of pelagic marine bacteria and its significance for substrate processing in the sea. Aquat Microb Ecol 10:223-230

Mohapatra BR, Fukami K (2004) Production of aminopeptidase by marine heterotrophic nanoflagellates. Aquat Microb Ecol 34:129-137

Müller-Niklas G, Schuster S, Kaltenböck E, Herndl GJ (1994) Organic content and bacterial metabolism in amorphous aggregations of the northern Adriatic Sea. Limnol Oceanogr 39:58-68

Obayashi Y, Suzuki S (2005) Proteolytic enzymes in coastal surface seawater: significant activity of endopeptidases and exopeptidases. Limnol Oceanogr 50:722-726

Obayashi Y, Suzuki S (in press) Adsorption of extracellular proteases in seawater onto filters during size fractionation. J Oceanogr

Pantoja S, Lee C, Marecek JF (1997) Hydrolysis of peptides in seawater and sediment. Mar Chem 57:25-40

> Rosso AL, Azam F (1987) Proteolytic activity in coastal oceanic waters: depth distribution and relationship to bacterial populations. Mar Ecol Prog Ser 41:231-240

Smith DC, Simon M, Alldredge AL, Azam F (1992) Intense hydrolytic enzyme activity on marine aggregates and implications for rapid particle dissolution. Nature 359: 139-141

Somville M, Billen G (1983) A method for determining exoproteolytic activity in natural waters. Limnol Oceanogr 28: 190-193

Stoecker DK, Gustafson DE Jr (2003) Cell-surface proteolytic activity of photosynthetic dinoflagellates. Aquat Microb Ecol 30:175-183

Vetter YA, Deming JW, Jumars PA, Krieger-Brockett BB (1998) A predictive model of bacterial foraging by means of freely released extracellular enzymes. Microb Ecol 36: $75-92$

Vives Rego J, Billen G, Fontigny A, Somville M (1985) Free and attached proteolytic activity in water environments. Mar Ecol Prog Ser 21:245-249

Wetzel RG (1991) Extracellular enzymatic interactions: storage, redistribution, and interspecific communication. In: Chróst RJ (ed) Microbial enzymes in aquatic environments. Springer-Verlag, New York, p 6-28 